\title{
Effects of stratospheric ozone recovery on photochemistry and ozone air quality in the troposphere
}

\author{
H. Zhang ${ }^{1}$, S. Wu ${ }^{2}$, Y. Huang ${ }^{1}$, and Y. Wang ${ }^{3,4}$ \\ ${ }^{1}$ Department of Geological and Mining Engineering and Sciences, Michigan Technological University, Houghton, \\ Michigan, USA \\ ${ }^{2}$ Atmospheric Sciences Program, Department of Geological and Mining Engineering and Sciences and Department of Civil \\ and Environmental Engineering, Michigan Technological University, Houghton, Michigan, USA \\ ${ }^{3}$ Ministry of Education Key Laboratory for Earth System Modeling, Center for Earth System Science, Institute for Global \\ Change Studies, Tsinghua University, Beijing, China \\ ${ }^{4}$ Department of Marine Science, Texas A\&M University at Galveston, Galveston, Texas, USA
}

Correspondence to: S. Wu (slwu@mtu.edu)

Received: 14 July 2013 - Published in Atmos. Chem. Phys. Discuss.: 20 August 2013

Revised: 7 March 2014 - Accepted: 10 March 2014 - Published: 23 April 2014

\begin{abstract}
There has been significant stratospheric ozone depletion since the late 1970 s due to ozone-depleting substances (ODSs). With the implementation of the Montreal Protocol and its amendments and adjustments, stratospheric ozone is expected to recover towards its pre-1980 level in the coming decades. In this study, we examine the implications of stratospheric ozone recovery for the tropospheric chemistry and ozone air quality with a global chemical transport model (GEOS-Chem). With a full recovery of the stratospheric ozone, the projected increases in ozone column range from $1 \%$ over the low latitudes to more than $10 \%$ over the polar regions. The sensitivity factor of troposphere ozone photolysis rate, defined as the percentage changes in surface ozone photolysis rate for $1 \%$ increase in stratospheric ozone column, shows significant seasonal variation but is always negative with absolute value larger than one. The expected stratospheric ozone recovery is found to affect the tropospheric ozone destruction rates much more than the ozone production rates. Significant decreases in surface ozone photolysis rates due to stratospheric ozone recovery are simulated. The global average tropospheric $\mathrm{OH}$ decreases by $1.7 \%$, and the global average lifetime of tropospheric ozone increases by $1.5 \%$. The perturbations to tropospheric ozone and surface ozone show large seasonal and spatial variations. General increases in surface ozone are calculated for each season, with increases by up to $0.8 \mathrm{ppbv}$ in the remote areas. Increases in ozone lifetime by up to $13 \%$ are found in the
\end{abstract}

troposphere. The increased lifetimes of tropospheric ozone in response to stratospheric ozone recovery enhance the intercontinental transport of ozone and global pollution, in particular for the summertime. The global background ozone attributable to Asian emissions is calculated to increase by up to $15 \%$ or $0.3 \mathrm{ppbv}$ in the Northern Hemisphere in response to the projected stratospheric ozone recovery.

\section{Introduction}

Significant decreases in stratospheric ozone driven by ozonedepleting substances (ODSs), in particular over the high latitudes, have been observed since the late 1970s (Farman et al., 1985). The decreases in stratospheric ozone have allowed increasing solar ultraviolet (UV) radiation, especially the UVB (280-315 nm) radiation, to reach into the troposphere and the earth's surface. Previous studies (McKenzie et al., 1991; Bais et al., 1993; Kerr and McElroy, 1993) have shown the general increases in ground-level solar UV-B radiation associated with the reduction of stratospheric ozone at various sites around the world.

Stratospheric ozone is expected to recover towards its pre1980 level (generally defined as the ozone recovery level) due to the reduction in ODSs as a result of the implementation of the Montreal Protocol as well as its amendments and adjustments. The recovery of stratospheric ozone could affect 
tropospheric ozone through two channels: (a) changes in the stratosphere-troposphere exchange (STE) of ozone and (b) changes in the UV radiation penetrating to the troposphere and consequently the photochemistry of tropospheric ozone and other species. Zeng et al. (2010) have studied the former effect, but the latter effect has not been investigated yet.

By changing the ozone column overhead, the expected stratospheric ozone recovery would directly affect the actinic flux and photolysis rates for tropospheric ozone. The photolysis of ozone followed by its reaction with water vapor is an important pathway for ozone destruction in the troposphere:

$\mathrm{O}_{3}+h v(\lambda \leq 330 \mathrm{~nm}) \rightarrow \mathrm{O}_{2}+\mathrm{O}\left({ }^{1} \mathrm{D}\right)$,

$\mathrm{O}\left({ }^{1} \mathrm{D}\right)+\mathrm{H}_{2} \mathrm{O} \rightarrow \mathrm{OH}+\mathrm{OH}$.

The above reactions also provide the dominant source for hydroxyl radical $(\mathrm{OH})$ in the troposphere, which controls the oxidizing capacity of the troposphere and thus the lifetimes of many atmospheric species (Thompson, 1992). On the other hand, the changes in UV radiation can also affect the photochemical production of ozone through the photolysis of $\mathrm{NO}_{2}$ :

$\mathrm{NO}_{2}+h v(\lambda \leq 400 \mathrm{~nm}) \rightarrow \mathrm{NO}+\mathrm{O}\left({ }^{3} \mathrm{P}\right)$,

$\mathrm{O}\left({ }^{3} \mathrm{P}\right)+\mathrm{O}_{2} \rightarrow \mathrm{O}_{3}$.

Liu and Trainer (1988) used a box model to study the response of tropospheric ozone and $\mathrm{OH}$ to an increase in UV radiation due to total zone reduction with fixed $\mathrm{NO}_{\mathrm{x}}$ concentration. It was found that tropospheric ozone changed in the same direction as column ozone, while in polluted regions an inverse relationship was seen. In addition, the change in tropospheric $\mathrm{OH}$ was independent of the $\mathrm{NO}_{\mathrm{x}}$ level. Thompson et al. (1989) also found that tropospheric ozone would increase with stratospheric ozone depletion at high $\mathrm{NO}_{\mathrm{x}}$ levels and decrease at low $\mathrm{NO}_{\mathrm{x}}$ levels by applying a onedimensional model. Fuglestvedt et al. (1994) found that the decline of stratospheric ozone would result in an increase in tropospheric $\mathrm{OH}$ and a general reduction in tropospheric $\mathrm{O}_{3}$ using a model simulating stratospheric ozone. Schnell et al. (1991) showed that a $17 \%$ decrease in measured surface ozone concentrations at the South Pole in the austral summer was mostly caused by the increases in surface radiation resulting from the stratospheric ozone hole where the $\mathrm{NO}_{\mathrm{x}}$ level is low.

The changes in tropospheric chemistry associated with the stratospheric ozone recovery also imply perturbations to surface ozone air quality and the intercontinental transport of ozone pollution. But previous studies investigating the evolution of ozone air quality in the coming decades (e.g., Johnson et al., 1999; Hauglustaine et al., 2005; Dentener et al., 2005; Wu et al., 2008a, b; Hegglin and Shepherd, 2009; Lang et al., 2012; Wang et al., 2013) have not accounted for the effect from stratospheric ozone recovery.

\section{Methodology and model description}

We investigate the responses of tropospheric chemistry and surface ozone air quality to stratospheric ozone recovery by carrying out a suite of sensitivity studies using a global 3-D chemical transport model, GEOS-Chem, which is driven by meteorological data from the Goddard Earth Observing System (GEOS) of the NASA Global Modeling and Assimilation office. Here we use GEOS-Chem version v8-03-01 driven by GEOS-5 meteorology with temporal resolution of $6 \mathrm{~h}$ ( $3 \mathrm{~h}$ for surface meteorological variables).

In this study, the simulations are run at a resolution of $4^{\circ}$ latitude by $5^{\circ}$ longitude with 47 vertical layers. GEOS-Chem has fully coupled $\mathrm{O}_{3}-\mathrm{NO}_{\mathrm{x}}-\mathrm{VOC}-$ aerosol chemistry and has been extensively evaluated and applied to a wide range of research topics related to atmospheric chemistry and air quality (e.g., Wang et al., 1998; Bey et al., 2001; Martin et al., 2002; Park et al., 2004; Evans and Jacob, 2005; Duncan et al., 2007; Wu et al., 2008a, b, 2012; Hudman et al., 2009; Hickman et al., 2010; Johnson et al., 2010; Huang et al., 2013; Kumar et al., 2013). The Linoz stratospheric ozone chemistry scheme (McLinden et al., 2000) is used. Photolysis rates in the troposphere are calculated using the Fast-J mechanism, which takes into account the effects of clouds and aerosols on photolysis rates (Wild et al., 2000). Seven wavelength bins with different widths cover the wavelength range from $291 \mathrm{~nm}$ to $850 \mathrm{~nm}$.

To derive the sensitivity of tropospheric photochemistry to stratospheric ozone recovery, two groups of simulations are performed: one as the control run and the other as the sensitivity run where the stratospheric ozone is assumed to be fully recovered to its pre-1980 levels. For both simulations, a whole year spin-up for the tropospheric chemistry and composition using 2005 meteorology is done, followed by a 3-year simulation using meteorology for 2006 to 2008 . Unless noted otherwise, all model results discussed in this study refer to the 3 -year averages. We follow Fioletov et al. (2002) and Chipperfield and Randel (2003) for the stratospheric ozone depletion in the past decades, which varies significantly with season and latitude. The expected increases in stratospheric ozone column associated with the ozone recovery in the coming decades are shown in Table 1. To isolate the potential impact of stratospheric ozone recovery on tropospheric chemistry through changes in UV radiation and therefore photolysis rates from other effects such as the changes in STE associated with transport (Zeng et al., 2010), we only apply the perturbations to the stratospheric ozone column in calculating the actinic flux and photolysis rates of various species in the troposphere. The STE of ozone remains unchanged from the control run to the sensitivity run. 

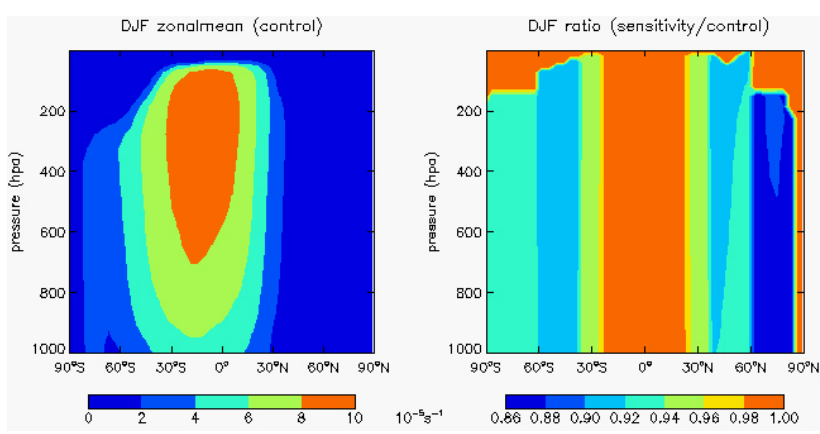

Fig. 1a. Changes in zonal mean photolysis rates of ozone $J\left(\mathrm{O}_{3}\right)$ due to stratospheric ozone recovery in December-February.

\section{Results}

To quantify the responses of photolysis rates, tropospheric chemistry, and surface ozone to stratospheric ozone recovery, a sensitivity analysis is performed by using the sensitivity factor as defined by Fuglestvedt et al. (1994):

$S_{X}=\frac{\frac{\Delta X}{X}}{\frac{\Delta \sum_{\mathrm{o}_{3}}}{\sum_{\mathrm{O}_{3}}}}$,

where $X$ is the variable of interest (e.g., photolysis rates, concentrations or global burden of any tropospheric species) and $\sum \mathrm{O}_{3}$ is the total column ozone. $\Delta X$ and $\Delta \sum \mathrm{O}_{3}$ represent the differences between results from the sensitivity run and the control run. Therefore, the value of $S_{x}$ indicates the percentage change in $X$ resulting from a $1 \%$ increase in total ozone column.

\subsection{Impacts on photolysis rates in troposphere}

The photolysis of $\mathrm{O}_{3}$ and $\mathrm{NO}_{2}$ are critical for the chemical destruction and production of tropospheric ozone respectively; therefore, we focus our analysis on the photolysis rates of these two species: $J\left(\mathrm{O}_{3}\right)$ and $J\left(\mathrm{NO}_{2}\right)$. The largest percentage change of $J\left(\mathrm{O}_{3}\right)$ of up to $22 \%$ is found in the springtime (September-November) over the southern polar region associated with the strongest stratospheric ozone recovery expected. Hegglin and Shepherd (2009) also found that ozone recovery could lead to the largest decrease in ultraviolet index in southern high latitudes during October, November, and December.

All of the sensitivity factors in Table 2 show negative values, indicating that the stratospheric ozone recovery would lead to less solar radiation in the troposphere, as expected. Voulgarakis et al. (2013) also demonstrated a similar relationship between the increase in overheard ozone and decrease in photolysis rate of Reaction (R2) from a multimodel study to examine how $\mathrm{OH}$ and methane lifetime would evolve from the present to the future. The calculated $S_{x}$ for $J\left(\mathrm{O}_{3}\right)$ is about $20-80$ times greater than $S_{x}$ for $J\left(\mathrm{NO}_{2}\right)$, reflecting the different absorption spectrums for $\mathrm{O}_{3}$ and $\mathrm{NO}_{2}$.
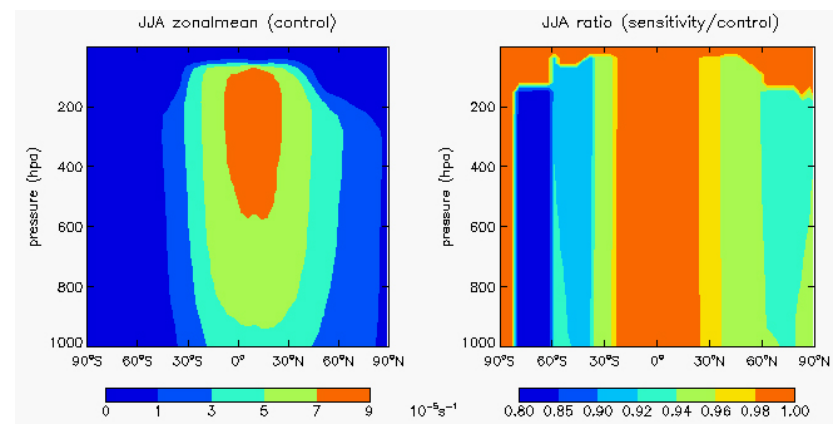

Fig. 1b. Same as Fig. 1a, but for June-August.
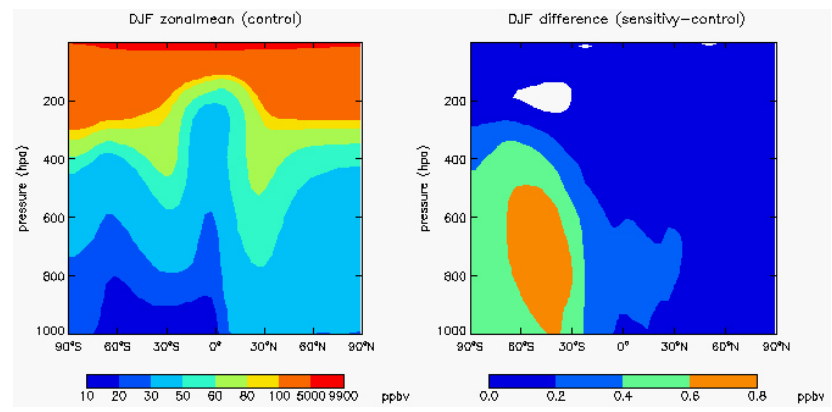

Fig. 2a. Changes in zonal mean $\mathrm{O}_{3}$ concentration due to stratospheric ozone recovery in December-February.

This implies that the stratospheric ozone recovery would have much stronger effects on the photochemical ozone destruction than the ozone production in the troposphere. The absolute values for $J\left(\mathrm{O}_{3}\right)$ are always larger than 1, implying that the percentage change of $J\left(\mathrm{O}_{3}\right)$ would be always larger than the percentage change for stratospheric ozone.

Figure $1 \mathrm{a}$ and $\mathrm{b}$ show the model-simulated zonal mean average $J\left(\mathrm{O}_{3}\right)$ in winter and summer seasons, respectively. The largest perturbations (up to $10 \%$ ) in $J\left(\mathrm{O}_{3}\right)$ are found over high latitudes during the summer season, reflecting the strong ozone recovery expected over those regions.

\subsection{Impacts on tropospheric ozone and $\mathrm{OH}$}

The changes in global budgets of tropospheric ozone and $\mathrm{OH}$ in response to stratospheric ozone recovery are summarized in Table 3. Due to the reduced photolysis rates in the troposphere associated with the stratosphere ozone recovery, the global chemical destruction rate of tropospheric ozone is calculated to decrease by $1 \%$, and the global average tropospheric $\mathrm{OH}$ is found to decrease by $1.7 \%$. The global tropospheric ozone burden is calculated to increase by $0.5 \%$. Our results are comparable to Spivakovsky et al. (2000), who reported that a $25 \%$ increase in the $\mathrm{O}_{3}$ column would lead to a $17 \%$ reduction in tropospheric $\mathrm{OH}$.

The fact that the decrease in ozone destruction rate is greater than the ozone production rate (as shown in Table 3 ) indicates that stratospheric ozone recovery would 
Table 1. Increase in stratospheric ozone column due to expected ozone recovery in the sensitivity run.

\begin{tabular}{lrrrrrrr}
\hline & $90-60^{\circ} \mathrm{S}$ & $60-35^{\circ} \mathrm{S}$ & $35-25^{\circ} \mathrm{S}$ & $25-25^{\circ} \mathrm{S}$ & $25-35^{\circ} \mathrm{N}$ & $35-60^{\circ} \mathrm{N}$ & $60-90^{\circ} \mathrm{N}$ \\
\hline DJF$^{*}$ & $4 \%$ & $6.3 \%$ & $3.15 \%$ & $1 \%$ & $2.8 \%$ & $5.6 \%$ & $12 \%$ \\
MAM $^{*}$ & $4 \%$ & $5.4 \%$ & $2.7 \%$ & $1 \%$ & $3.0 \%$ & $6 \%$ & $8 \%$ \\
JJA $^{*}$ & $16 \%$ & $5.9 \%$ & $2.95 \%$ & $1 \%$ & $1.75 \%$ & $3.5 \%$ & $4 \%$ \\
SON $^{*}$ & $16 \%$ & $6.2 \%$ & $3.1 \%$ & $1 \%$ & $2.1 \%$ & $4.2 \%$ & $4 \%$ \\
\hline
\end{tabular}

* DJF: December-February for Northern Hemisphere winter; MAM: March-May for Northern Hemisphere spring; JJA: June-August for Northern Hemisphere summer; SON: September-November for Northern Hemisphere fall.

Table 2. Sensitivity factors of average surface $J\left(\mathrm{O}_{3}\right)$ and $J\left(\mathrm{NO}_{2}\right)$.

\begin{tabular}{lrrrrrrr}
\hline & $90-60^{\circ} \mathrm{S}$ & $60-35^{\circ} \mathrm{S}$ & $35-25^{\circ} \mathrm{S}$ & $25-25^{\circ} \mathrm{N}$ & $25-35^{\circ} \mathrm{N}$ & $35-60^{\circ} \mathrm{N}$ & $60-90^{\circ} \mathrm{N}$ \\
\hline $\mathrm{DJF}\left(j \mathrm{O}_{3}\right)$ & -1.58 & -1.24 & -1.32 & -1.45 & -1.48 & -1.39 & -1.08 \\
$\operatorname{MAM}\left(j \mathrm{O}_{3}\right)$ & -1.45 & -1.22 & -1.38 & -1.53 & -1.42 & -1.43 & -1.38 \\
$\mathrm{JJA}\left(j \mathrm{O}_{3}\right)$ & -1.14 & -1.15 & -1.45 & -1.45 & -1.39 & -1.42 & -1.48 \\
$\mathrm{SON}\left(j \mathrm{O}_{3}\right)$ & -1.36 & -1.27 & -1.38 & -1.44 & -1.43 & -1.43 & -1.40 \\
$\operatorname{DJF}\left(j \mathrm{NO}_{2}\right)$ & -0.024 & -0.017 & -0.018 & -0.020 & -0.019 & -0.024 & -0.037 \\
$\mathrm{MAM}\left(j \mathrm{NO}_{2}\right)$ & -0.028 & -0.018 & -0.021 & -0.019 & -0.019 & -0.021 & -0.027 \\
$\mathrm{JJA}\left(j \mathrm{NO}_{2}\right)$ & -0.032 & -0.020 & -0.019 & -0.019 & -0.019 & -0.020 & -0.024 \\
$\operatorname{SON}\left(j \mathrm{NO}_{2}\right)$ & -0.021 & -0.018 & -0.019 & -0.020 & -0.019 & -0.020 & -0.027 \\
\hline
\end{tabular}

have more impacts on Reactions (R1)-(R2) rather than Reactions (R3)-(R4). Table 3 also shows that the reduced chemical destruction rate of tropospheric ozone would increase the lifetime of tropospheric ozone. The calculated average ozone lifetime in the troposphere is 32.8 days and 33.3 days for control run and sensitivity run, respectively, reflecting a $1.5 \%$ increase. Changes in ozone lifetime in the troposphere show strong seasonal and spatial variations with the largest increase of up to $13 \%$ found in the southern high latitudes in the springtime (September to November), associated with the strongest stratospheric ozone recovery expected.

Figure $2 \mathrm{a}$ and $\mathrm{b}$ show the zonal mean concentrations for tropospheric ozone as well as the impacts due to stratospheric ozone recovery for winter and summer seasons. As we can see from the figures, the effects of stratospheric ozone recovery exhibit significant seasonal and spatial variations. $\mathrm{O}_{3}$ concentration in the lower troposphere will be most affected, in particular for the summertime. The largest increases of up to $4 \%$ are found in the lower troposphere over southern midlatitudes in December-February. This is in contrast to the effects associated with changes in STE (Collins et al., 2003), which were more pronounced for the upper troposphere during winter seasons.

\subsection{Impacts on surface ozone and intercontinental transport of ozone}

General increases in surface ozone due to stratospheric ozone recovery are calculated for all seasons. As we can see from Fig. $3 \mathrm{a}$ and $\mathrm{b}$, which shows the changes in surface ozone for December-February and June-August respectively, the
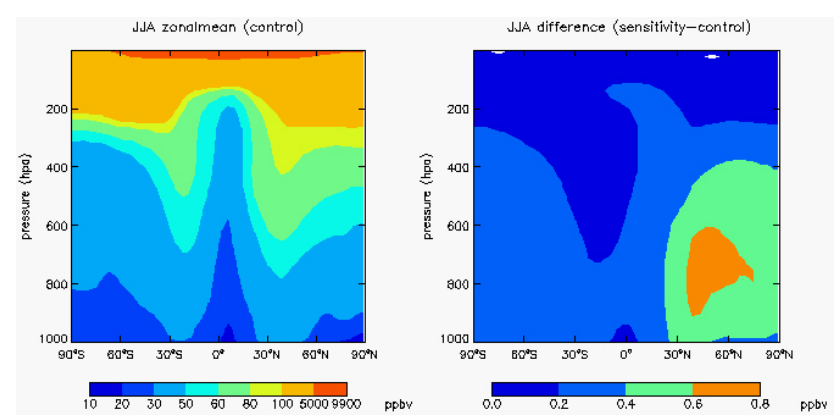

Fig. 2b. Same as Fig. 2a, but for June-August.

largest increases (up to $0.8 \mathrm{ppbv}$ or $5 \%$ ) are always found over remote oceans (such as the North Atlantic and Mediterranean regions), which are typical ozone sink regions featured by ozone destruction rates higher than production rates. This reflects the fact that stratospheric ozone recovery would decrease the photochemical ozone destruction rates much more than the ozone production rates in the troposphere. The largest percentage change of surface ozone is found in the summertime, while the smallest change is found in the wintertime, reflecting the strongest photochemical activities during summertime.

To further investigate the impacts of stratospheric ozone recovery on the intercontinental transport of ozone pollution in the troposphere, we carried out additional sensitivity model simulations to examine the continental outflow of ozone from Asia as a case study. Following Wu et al. (2009), we turned off both natural and anthropogenic emissions of ozone precursors from Asia (the region of $63-150^{\circ} \mathrm{E}$ and 
Table 3. Change in global tropospheric ozone and $\mathrm{OH}$ due to stratospheric ozone recovery.

\begin{tabular}{lrrrrr}
\hline & $\begin{array}{r}\text { Ozone burden } \\
\left(\mathrm{Tg} \mathrm{a}^{-1}\right)\end{array}$ & $\begin{array}{r}P\left(\mathrm{O}_{\mathrm{x}}\right)^{\mathrm{a}} \\
\left(\mathrm{Tg} \mathrm{a}^{-1}\right)\end{array}$ & $\begin{array}{r}L\left(\mathrm{O}_{\mathrm{x}}\right)^{\mathrm{a}} \\
\left(\mathrm{Tg} \mathrm{a}^{-1}\right)\end{array}$ & $\begin{array}{r}\text { Ozone lifetime }^{\mathrm{b}} \\
(\text { days })\end{array}$ & $\begin{array}{r}\text { OH }\left(10^{6}\right. \\
\left.\text { molecules cm }^{-3}\right)\end{array}$ \\
\hline Control & 384 & 4815 & 4287 & 32.8 & 1.15 \\
Sensitivity & $386(+0.5 \%)$ & $4778(-0.8 \%)$ & $4243(-1.0 \%)$ & $33.3(+1.5 \%)$ & $1.13(-1.7 \%)$ \\
\hline
\end{tabular}

a $P\left(\mathrm{O}_{\mathrm{x}}\right)$ and $L\left(\mathrm{O}_{\mathrm{x}}\right)$ are the chemical production and loss rates, respectively, for $\mathrm{O}_{\mathrm{x}}$, which is defined as

$\mathrm{O}_{\mathrm{x}} \equiv \mathrm{O}_{3}+\mathrm{O}+\mathrm{NO}_{2}+2 \times \mathrm{NO}_{3}+3 \times \mathrm{N}_{2} \mathrm{O}_{5}+\mathrm{PANs}+\mathrm{HNO}_{3}+\mathrm{HNO}_{4}$.

${ }^{b}$ Ozone lifetime here refers to the chemical lifetime of ozone due to chemical destruction, which is calculated by dividing total

tropospheric ozone burden with the total ozone destruction rate in the troposphere.
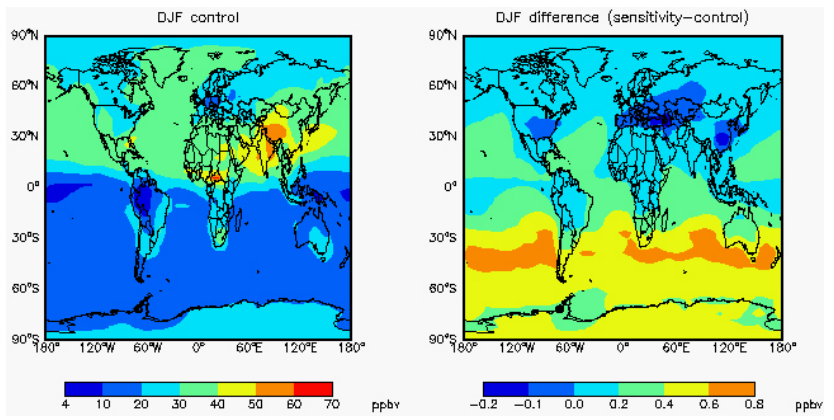

Fig. 3a. Changes in surface $\mathrm{O}_{3}$ concentration due to stratospheric ozone recovery in December-February.

$10-58^{\circ} \mathrm{N}$ ) in the model to derive the intercontinental transport of ozone pollution from Asia. Four groups of simulations are performed for the 3-year period of 2006-2008 (our analysis is based on the 3-year average results): (1) control run, (2) control run without ozone precursor emissions from Asia, (3) sensitivity run with stratospheric ozone recovery perturbations, and (4) sensitivity run with stratospheric ozone recovery perturbations and without ozone precursor emissions from Asia. Groups 1 and 3 are the control run and sensitivity run, respectively, described in Sect. 2. Group 2 and group 4 have the same setup as group 1 and group 3 except for the turning off of Asian ozone precursor emissions.

Results from these four groups of simulations are compared with each other to derive the impacts of stratospheric ozone recovery on intercontinental transport of ozone (Fig. 4a). The difference between simulation 1 and 2 results represent the tropospheric ozone attributable to Asian ozone precursors emissions (top left panel in Fig. 4a) while the difference between simulation 3 and 4 results represent the tropospheric ozone attributable to Asian ozone precursor emissions under stratospheric ozone recovery scenario (top right panel in Fig. 4a). The impacts of stratospheric ozone recovery on intercontinental transport of ozone from Asia are derived by further comparing these two groups of "difference" results (bottom panels in Fig. 4a).

As can be seen from Fig. 4a, the stratospheric ozone recovery could enhance the global background ozone attributable to Asian emissions by up to $15 \%$ in the Northern Hemi-
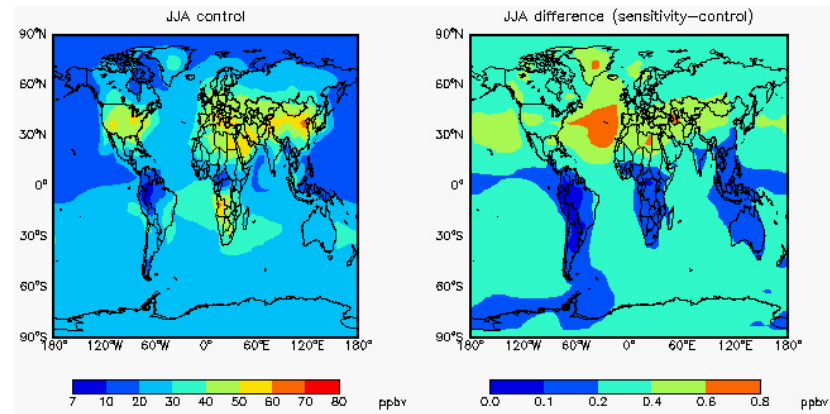

Fig. 3b. Same as Fig. 3a, but for June-August.

sphere. The impacts of stratospheric ozone recovery on continental outflow of ozone pollution from Asia show a strong seasonal variation: they are weakest in the wintertime but peak in the summer when there is abundant UV radiation available, indicating that the seasonality is dominated by the photochemistry rather than atmospheric transport. In comparison, Doherty et al. (2013) found that climate change affects the intercontinental transport of ozone mainly through changes in ozone chemistry but not atmospheric transport.

Figure $4 \mathrm{~b}$ shows the surface ozone over North America (NA: defined as of $60^{\circ} \mathrm{W}-125^{\circ} \mathrm{E}$ and $15-55^{\circ} \mathrm{N}$ ) attributable to Asian emissions as well as the impacts associated with stratospheric ozone recovery in the summertime. Increases in surface ozone by up to $0.25 \mathrm{ppbv}$ are calculated throughout the United States with the maximum increase found over the northwest. Observational data have demonstrated that background ozone in the United States has been increasing over the past decades (Jaffe et al., 2003; Jaffe and Ray, 2007). Wu et al. (2008b) showed that climate change would decrease the summertime policy-relevant background (PRB) ozone over the US by up to 2 ppbv except for over the Great Plains. The increase in intercontinental transport of ozone and, consequently, background ozone due to stratospheric ozone recovery could have important implications for the PRB ozone and air quality policy and management in the future. 

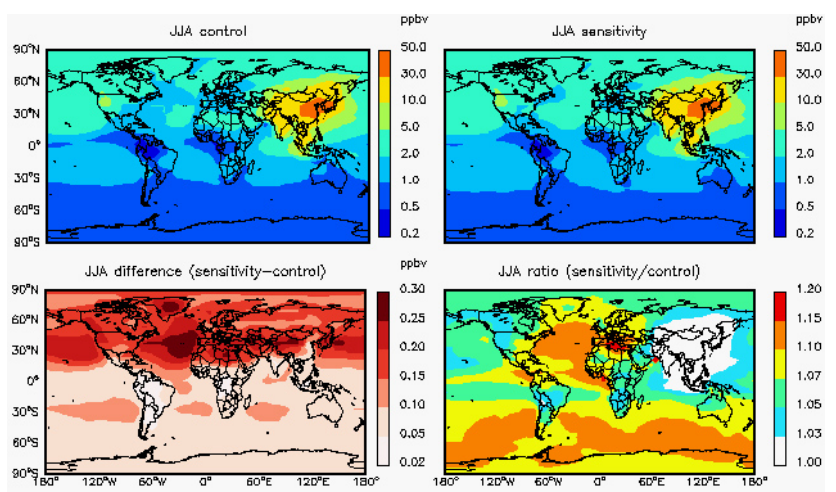

Fig. 4a. June-August average surface $\mathrm{O}_{3}$ concentration attributable to Asian emissions and the impacts from stratospheric ozone recovery.

\section{Conclusions}

We examine the potential impacts on tropospheric chemistry and ozone air quality from the expected stratospheric ozone recovery in the coming decades with a chemical transport model. With the full recovery of stratospheric ozone to its pre-1980 level, we found significant decreases in photolysis rates for tropospheric ozone, with the surface $\mathrm{O}_{3}$ photolysis rates being decreased by up to $22 \%$. The sensitivity factor for surface ozone photolysis rate, defined as the percentage changes in surface ozone photolysis rate for $1 \%$ change in stratospheric ozone, is always negative with absolute values larger than one. Compared to tropospheric ozone, tropospheric $\mathrm{NO}_{2}$ shows much weaker sensitivity to stratospheric ozone recovery. As a consequence, the stratospheric ozone recovery leads to decreases in both the photochemical destruction and production of tropospheric ozone, but the decreases in destruction are much stronger than those for production.

In response to the projected stratospheric ozone recovery, we find significant increases in the lifetimes of tropospheric ozone, by up to $13 \%$ over the southern high latitudes. The global average tropospheric ozone lifetime increases by $1.5 \%$, and the global tropospheric ozone burden increases by $0.5 \%$ while the average tropospheric $\mathrm{OH}$ concentration is calculated to decrease by $1.7 \%$. The perturbations to tropospheric chemistry and surface ozone show strong seasonal and spatial variations. The largest perturbations are generally found in the lower troposphere and during summertime when there are strong photochemical activities. General increases in surface ozone are calculated for each season associated with the stratospheric ozone recovery, in particular over oceans where surface ozone can increase by up to $5 \%$ during summertime.

We also find that the stratospheric ozone recovery would enhance the intercontinental transport of ozone pollution. The global background ozone attributable to Asian emissions is calculated to increase by up to $20 \%$ in the Northern Hemi-
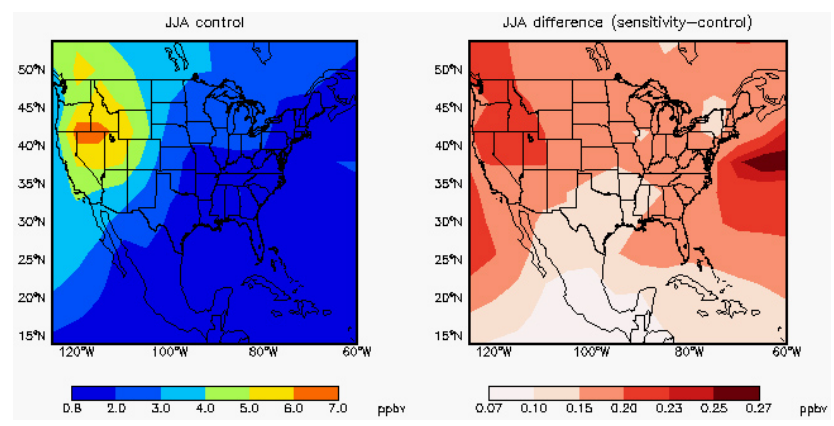

Fig. 4b. Same as Fig. 4a, but zoom-in plot for North America.

sphere in response to the projected stratospheric ozone recovery. The enhancements in intercontinental transport of ozone show a strong seasonality with peaks in summer.

The findings from this study imply that the long-term planning and management of ozone air quality in the coming decades should take into account the impacts from stratospheric ozone recovery. This study focuses on the potential impacts on tropospheric ozone from the expected stratospheric ozone recovery and does not account for the impacts from climate change, which can also affect the future evolution of atmospheric composition and air quality (e.g., Johnson et al., 1999; Hauglustaine et al., 2005; Wu et al., 2008a, b; Bloomer et al., 2009; Weaver et al., 2009; Lang et al., 2012; Dawson et al., 2014; Wang et al., 2013).

Acknowledgements. This work was initially inspired by a discussion with Daniel J. Jacob at Harvard University. This publication was made possible by a US EPA grant (grant 83518901). Its contents are solely the responsibility of the grantee and do not necessarily represent the official views of the US EPA. Further, US EPA does not endorse the purchase of any commercial products or services mentioned in the publication.

Edited by: M. Kopacz

\section{References}

Bais, A. F., Zerefos, C. S., Meleti, C., Ziomas, I. C., and Tourpali, K.: Spectral measurements of solar UVB radiation and its relations to total ozone, $\mathrm{SO}_{2}$, and clouds, J. Geophys. Res.-Atmos., 98, 5199-5204, doi:10.1029/92jd02904, 1993.

Bey, I., Jacob, D. J., Yantosca, R. M., Logan, J. A., Field, B. D., Fiore, A. M., Li, Q. B., Liu, H. G. Y., Mickley, L. J., and Schultz, M. G.: Global modeling of tropospheric chemistry with assimilated meteorology: Model description and evaluation, J. Geophys. Res.-Atmos., 106, 23073-23095, 2001.

Bloomer, B. J., Stehr, J. W., Piety, C. A., Salawitch, R. J., and Dickerson, R. R.: Observed relationships of ozone air pollution with temperature and emissions, Geophys. Res. Lett., 36, L09803, doi:10.1029/2009GL037308, 2009.

Chipperfield, M. P. and Randel, W. J.: Global Ozone: Past and future, Chapter 4, in: Scientific Assessment of Ozone Depletion: 
2002, Global Ozone Research and Monitoring Project-Report No. 47, Geneva, 2003.

Collins, W. J., Derwent, R. G., Garnier, B., Johnson, C. E., Sanderson, M. G., and Stevenson, D. S.: Effect of stratospheretroposphere exchange on the future tropospheric ozone trend, J. Geophys. Res.-Atmos., 108, 8528, doi:10.1029/2002jd002617, 2003.

Dawson, J. P., Bloomer, B. J., Winner, D. A., and Weaver, C. P.: Understanding the meteorological drivers of U.S. particulate matter concentrations in a changing climate, B. Am. Meteorol. Soc., doi:10.1175/BAMS-D-12-00181.1, in press, 2014.

Dentener, F., Stevenson, D., Cofala, J., Mechler, R., Amann, M., Bergamaschi, P., Raes, F., and Derwent, R.: The impact of air pollutant and methane emission controls on tropospheric ozone and radiative forcing: CTM calculations for the period 1990 2030, Atmos. Chem. Phys., 5, 1731-1755, doi:10.5194/acp-51731-2005, 2005.

Doherty, R. M., Wild, O., Shindell, D. T., Zeng, G., MacKenzie, I. A., Collins, W. J., Fiore, A. M., Stevenson, D. S., Dentener, F. J., Schultz, M. G., Hess, P., Derwent, R. G., and Keating, T. J.: Impacts of climate change on surface ozone and intercontinental ozone pollution: A multi-model study, J. Geophys. Res.-Atmos., 118, 3744-3763, doi:10.1002/jgrd.50266, 2013.

Duncan, B. N., Logan, J. A., Bey, I., Megretskaia, I. A., Yantosca, R. M., Novelli, P. C., Jones, N. B., and Rinsland, C. P.: Global budget of CO, 1988-1997: Source estimates and validation with a global model, J. Geophys. Res.-Atmos., 112, D22301, doi:10.1029/2007jd008459, 2007.

Evans, M. J. and Jacob, D. J.: Impact of new laboratory studies of $\mathrm{N}_{2} \mathrm{O}_{5}$ hydrolysis on global model budgets of tropospheric nitrogen oxides, ozone, and OH, Geophys. Res. Lett., 32, L09813, doi:10.1029/2005g1022469, 2005.

Farman, J. C., Gardiner, B. G., and Shanklin, J. D.: Large losses of total ozone in antarctica reveal seasonal CLO $/ \mathrm{NO}_{X}$ interaction, Nature, 315, 207-210, doi:10.1038/315207a0, 1985.

Fioletov, V. E., Bodeker, G. E., Miller, A. J., McPeters, R. D., and Stolarski, R.: Global and zonal total ozone variations estimated from ground-based and satellite measurements: 1964-2000, J. Geophys. Res., 107, 4647, doi:10.1029/2001jd001350, 2002.

Fuglestvedt, J. S., Jonson, J. E., and Isaksen, I. S. A.: Effects of reductions in stratospheric ozone on tropospheric chemistry through changes in photolysis rates, Tellus B, 46, 172-192, doi:10.1034/j.1600-0889.1992.t01-3-00001.x-i1, 1994.

Hauglustaine, D. A., Lathiere, J., Szopa, S., and Folberth, G. A.: Future tropospheric ozone simulated with a climatechemistry-biosphere model, Geophys. Res. Lett., 32, L24807, doi:10.1029/2005g1024031, 2005.

Hegglin, M. I. and Shepherd, T. G.: Large climate-induced changes in ultraviolet index and stratosphere-to-troposphere ozone flux, Nat. Geosci., 2, 687-691, doi:10.1038/ngeo604, 2009.

Hickman, J. E., Wu, S., Mickley, L. J., and Lerdau, M. T.: Kudzu (Pueraria montana) invasion doubles emissions of nitric oxide and increases ozone pollution, P. Natl. Acad. Sci. USA, 107, 10115-10119, doi:10.1073/pnas.0912279107, 2010.

Huang, Y., Wu, S., Dubey, M. K., and French, N. H. F.: Impact of aging mechanism on model simulated carbonaceous aerosols, Atmos. Chem. Phys., 13, 6329-6343, doi:10.5194/acp-13-63292013,2013
Hudman, R. C., Murray, L. T., Jacob, D. J., Turquety, S., Wu, S., Millet, D. B., Avery, M., Goldstein, A. H., and Holloway, J.: North American influence on tropospheric ozone and the effects of recent emission reductions: Constraints from ICARTT observations, J. Geophys. Res.-Atmos., 114, D07302, doi:10.1029/2008jd010126, 2009.

Jaffe, D. and Ray, J.: Increase in surface ozone at rural sites in the western US, Atmos. Environ., 41, 5452-5463, doi:10.1016/j.atmosenv.2007.02.034, 2007.

Jaffe, D., Price, H., Parrish, D., Goldstein, A., and Harris, J.: Increasing background ozone during spring on the west coast of North America, Geophys. Res. Lett., 30, 1613, doi:10.1029/2003g1017024, 2003.

Johnson, C. E., Collins, W. J., Stevenson, D. S., and Derwent, R. G.: Relative roles of climate and emissions changes on future tropospheric oxidant concentrations, J. Geophys. Res.-Atmos., 104, 18631-18645, 1999.

Johnson, M. S., Meskhidze, N., Solmon, F., Gasso, S., Chuang, P. Y., Gaiero, D. M., Yantosca, R. M., Wu, S., Wang, Y., and Carouge, C.: Modeling dust and soluble iron deposition to the South Atlantic Ocean, J. Geophys. Res.-Atmos., 115, D15202, doi:10.1029/2009jd013311, 2010.

Kerr, J. B. and McElroy, C. T.: Evidence for large upward trends of ultraviolet-B radiation linked to ozone depletion, Science, 262, 1032-1034, doi:10.1126/science.262.5136.1032, 1993.

Kumar, A., Wu, S., Weise, M. F., Honrath, R., Owen, R. C., Helmig, D., Kramer, L., Val Martin, M., and Li, Q.: Free-troposphere ozone and carbon monoxide over the North Atlantic for 20012011, Atmos. Chem. Phys., 13, 12537-12547, doi:10.5194/acp13-12537-2013, 2013.

Lang, C., Waugh, D. W., Olsen, M. A., Douglass, A. R., Liang, Q., Nielsen, J. E., Oman, L. D., Pawson, S., and Stolarski, R. S.: The impact of greenhouse gases on past changes in tropospheric ozone, J. Geophysical Res.-Atmos., 117, D23304, doi:10.1029/2012jd018293, 2012.

Liu, S. C. and Trainer, M.: Responses of the tropospheric ozone and odd hydrogen radicals to column ozone change, J. Atmos. Chem., 6, 221-232, doi:10.1007/bf00053857, 1988.

Martin, R. V., Chance, K., Jacob, D. J., Kurosu, T. P., Spurr, R. J. D., Bucsela, E., Gleason, J. F., Palmer, P. I., Bey, I., Fiore, A. M., Li, Q. B., Yantosca, R. M., and Koelemeijer, R. B. A.: An improved retrieval of tropospheric nitrogen dioxide from GOME, J. Geophys. Res.-Atmos., 107, 4437, doi:10.1029/2001jd001027, 2002.

McKenzie, R. L., Matthews, W. A., and Johnston, P. V.: The relationship between erythemal UV and ozone, derived from spectral irradiance measurements, Geophys. Res. Lett., 18, 2269-2272, doi:10.1029/91g102786, 1991.

McLinden, C. A., Olsen, S. C., Hannegan, B., Wild, O., Prather, M. J., and Sundet, J.: Stratospheric ozone in 3-D models: A simple chemistry and the cross-tropopause flux, J. Geophys. Res.Atmos., 105, 14653-14665, doi:10.1029/2000jd900124, 2000.

Park, R. J., Jacob, D. J., Field, B. D., Yantosca, R. M., and Chin, M.: Natural and transboundary pollution influences on sulfate-nitrate-ammonium aerosols in the United States: Implications for policy, J. Geophys. Res.-Atmos., 109, D15204, doi:10.1029/2003jd004473, 2004.

Schnell, R. C., Liu, S. C., Oltmans, S. J., Stone, R. S., Hofmann, D. J., Dutton, E. G., Deshler, T., Sturges, W. T., Harder, J. W., 
Sewell, S. D., Trainer, M., and Harris, J. M.: Decrease of summer tropospheric ozone concentrations in Antarctica, Nature, 351, 726-729, doi:10.1038/351726a0, 1991.

Spivakovsky, C. M., Logan, J. A., Montzka, S. A., Balkanski, Y. J., Foreman-Fowler, M., Jones, D. B. A., Horowitz, L. W., Fusco, A. C., Brenninkmeijer, C. A. M., Prather, M. J., Wofsy, S. C., and McElroy, M. B.: Three-dimensional climatological distribution of tropospheric OH: Update and evaluation, J. Geophys. Res.Atmos., 105, 8931-8980, doi:10.1029/1999jd901006, 2000.

Thompson, A. M., Stewart, R. W., Owens, M. A., and Herwehe, J. A.: Sensitivity of tropospheric oxidants to global chemical and climate change, Atmos. Environ., 23, 519-532, doi:10.1016/0004-6981(89)90001-2, 1989.

Thompson, A. M.: The oxidizing capacity of the earths atmosphere - probable past and future changes, Science, 256, 1157-1165, 1992.

Voulgarakis, A., Naik, V., Lamarque, J.-F., Shindell, D. T., Young, P. J., Prather, M. J., Wild, O., Field, R. D., Bergmann, D., CameronSmith, P., Cionni, I., Collins, W. J., Dalsøren, S. B., Doherty, R. M., Eyring, V., Faluvegi, G., Folberth, G. A., Horowitz, L. W., Josse, B., MacKenzie, I. A., Nagashima, T., Plummer, D. A., Righi, M., Rumbold, S. T., Stevenson, D. S., Strode, S. A., Sudo, K., Szopa, S., and Zeng, G.: Analysis of present day and future $\mathrm{OH}$ and methane lifetime in the ACCMIP simulations, Atmos. Chem. Phys., 13, 2563-2587, doi:10.5194/acp-13-25632013, 2013.

Wang, Y., Shen, L., Wu, S., Mickley, L., He, J., and Hao, J.: Sensitivity of surface ozone over China to 2000-2050 global changes of climate and emissions, Atmos. Environ., 75, 374-382, doi:10.1016/j.atmosenv.2013.04.045, 2013.

Wang, Y. H., Jacob, D. J., and Logan, J. A.: Global simulation of tropospheric $\mathrm{O}-3-\mathrm{NO}_{\mathrm{X}}$-hydrocarbon chemistry 3 . Origin of tropospheric ozone and effects of nonmethane hydrocarbons, J. Geophys. Res.-Atmos., 103, 10757-10767, 1998.

Weaver, C. P., Liang, X.-Z., Zhu, J., Adams, P. J., Amar, P., Avise, J., Caughey, M., Chen, J., Cohen, R. C., Cooter, E., Dawson, J. P., Gilliam, R., Gilliland, A., Goldstein, A. H., Grambsch, A., Grano, D., Guenther, A., Gustafson, W. I., Harley, R. A., He, S., Hemming, B., Hogrefe, C., Huang, H.-C., Hunt, S. W., Jacob, D. J., Kinney, P. L., Kunkel, K., Lamarque, J.-F., Lamb, B., Larkin, N. K., Leung, L. R., Liao, K.-J., Lin, J.-T., Lynn, B. H., Manomaiphiboon, K., Mass, C., McKenzie, D., Mickley, L. J., O'Neill, S. M., Nolte, C., Pandis, S. N., Racherla, P. N., Rosenzweig, C., Russell, A. G., Salathé, E., Steiner, A. L., Tagaris, E., Tao, Z., Tonse, S., Wiedinmyer, C., Williams, A., Winner, D. A., Woo, J.-H., Wu, S., and Wuebbles, D. J.: A preliminary synthesis of modeled climate change impacts on U.S. regional ozone concentrations, B. Am. Meteorol. Soc., 90, 1843-1863, 2009.
Wild, O., Zhu, X., and Prather, M. J.: Fast-j: Accurate simulation of in- and below-cloud photolysis in tropospheric chemical models, J. Atmos. Chem., 37, 245-282, doi:10.1023/a:1006415919030, 2000.

Wu, S., Mickley, L. J., Leibensperger, E. M., Jacob, D. J., Rind, D., and Streets, D. G.: Effects of 2000-2050 global change on ozone air quality in the United States, J. Geophys. Res.-Atmos., 113, D06302, doi:10.1029/2007jd008917, 2008a.

Wu, S., Mickley, L. J., Kaplan, J. O., and Jacob, D. J.: Impacts of changes in land use and land cover on atmospheric chemistry and air quality over the 21st century, Atmos. Chem. Phys., 12, 15971609, doi:10.5194/acp-12-1597-2012, 2012.

Wu, S. L., Mickley, L. J., Jacob, D. J., Rind, D., and Streets, D. G.: Effects of 2000-2050 changes in climate and emissions on global tropospheric ozone and the policy-relevant background surface ozone in the United States, J. Geophys. Res.-Atmos., 113, D18312, doi:10.1029/2007jd009639, 2008 b.

Wu, S. L., Duncan, B. N., Jacob, D. J., Fiore, A. M., and Wild, O.: Chemical nonlinearities in relating intercontinental ozone pollution to anthropogenic emissions, Geophys. Res. Lett., 36, L05806, doi:10.1029/2008g1036607, 2009.

Zeng, G., Morgenstern, O., Braesicke, P., and Pyle, J. A.: Impact of stratospheric ozone recovery on tropospheric ozone and its budget, Geophys. Res. Lett., 37, L09805, doi:10.1029/2010g1042812, 2010. 